University of Michigan Law School

University of Michigan Law School Scholarship Repository

Law \& Economics Working Papers

$11-1-2014$

\title{
Profits v. Purpose: Hybrid Companies and the Charitable Dollar
}

\author{
Rachel Culley \\ Massachusetts Appeals Court, rachel.culley@post.harvard.edu \\ Jill R. Horwitz \\ University of Michigan Law School, horwitz@law.ucla.edu
}

Follow this and additional works at: https://repository.law.umich.edu/law_econ_current

Part of the Organizations Law Commons, and the Tax Law Commons

\section{Working Paper Citation}

Culley, Rachel and Horwitz, Jill R., "Profits v. Purpose: Hybrid Companies and the Charitable Dollar" (2014). Law \& Economics Working Papers. 48.

https://repository.law.umich.edu/law_econ_current/art48

This Article is brought to you for free and open access by University of Michigan Law School Scholarship Repository. It has been accepted for inclusion in Law \& Economics Working Papers by an authorized administrator of University of Michigan Law School Scholarship Repository. For more information, please contact mlaw.repository@umich.edu. 


\section{Profits v. Purpose: Hybrid Companies and the Charitable Dollar}

\section{Rachel Culley and Jill R. Horwitz}

\section{INTRODUCTION}

Government programs and regulations are not the only means of advancing public purposes. Laws that enable people to organize to pursue diverse goals also advance the public interest. For-profit corporations raise capital for profitable commerce; charities and other nonprofits dedicate themselves to missions in the public interest, whether through support by voluntary contribution, government grants, or fees for services. In each case, the presumption - often valid - is that organizations pursuing their own purposes, whether the protection of birds or the sale of pizza, advance the general public welfare.

Social entrepreneurs have frequently attempted to have the best of both worlds and blur the boundaries between nonprofit and for-profit organizational ownership types. They have introduced structures and incentives typical of profit-seeking businesses into organizations with charitable goals, assuming that an institutional setting focused on profits will outperform one focused on charity. They have encouraged for-profits to donate to charities, create affiliated foundations, and, with the blessing of state stake-holder legislation, attend to social goals aside from profit-maximization. Some have created nonprofit/for-profit joint ventures and publicprivate partnerships, and endorsed the privatization of traditional government functions and activities.

Attracted by the benefits of such blurring, several jurisdictions in the United States, Great Britain, and Canada have allowed social entrepreneurs to take a significant further step in 
combining legal elements from nonprofit and for-profit forms. They have authorized several types of hybrid corporations, but have gained the most experience with a particular variant of the limited liability company. In 2005, the United Kingdom introduced the Community Interest Company into its Company Act. In the US, the Low-Profit Limited Liability Company (L3C) is rapidly proliferating across state business codes. In Canada, British Columbia adopted an analogous hybrid structure, the Community Contribution Company (C3) through an amendment to the Business Corporations Act in 2012, and Nova Scotia is following suit.

The idea underlying hybrids is that, by drawing both on the for-profit motive to seek profits and the nonprofit motive to advance the public good, they will serve public purposes in a new, maybe better, way than traditional forms. This view has some plausibility. After all, as Professor Rod Dobell has observed, “[p]eople interact differently in different institutional settings, with their different reward systems or incentive structures." ${ }^{\prime 1}$ Indeed, proponents have made expansive claims for hybrids - claims related to the benefits of leveraging charitable dollars for social purposes, marketing to potential investors, establishing credibility with the public, harnessing the superior efficiency of for-profit organization and market-based practices, providing historical continuity, and enhancing the ability for donors/investors to control social purpose organizations - all of which we address in this chapter. In addition to these broad justifications for hybrids, we also address the narrow, legal justification for the American L3C because it highlights the difficulty of blending forms.

In evaluating the claims in favor of hybrids, we highlight the potential costs of blending nonprofit and for-profit goals into one entity. In particular, we conclude that the US L3C is, at a minimum, unnecessary and maybe undesirable. In doing so, we identify four types of problems 
raised by the L3C, and to at least some extent by other hybrid models: 1) their internal, legal incoherence; 2) the risk to charitable assets and potential for inappropriate use of tax subsidies; 3) the problematic assumption that for-profits are more efficient than nonprofit or government alternatives; and 4) the potentially inappropriate use of government imprimatur. We recognize, however, the increasing and unyielding limits on the ability of nonprofits to raise capital. L3Cs may well offer a new method for accessing capital while avoiding conversions to fully for-profit ownership. Yet despite the potential benefits, we argue that the risks to charitable dollars and purposes likely outweigh the benefits of hybrid entities.

\section{FOR-PROFIT MEANS FOR NONPROFIT ENDS}

To establish a new private organization, its founders must choose a legal structure. A social entrepreneur may use her own person as the legal entity, providing labor or personal assets to advance her goals. Founders more typically establish a separate organization. For centuries, such private organizations have come in two broad forms, for-profit and nonprofit, each believed to advance general welfare but in different ways. For-profits typically benefit society by selling goods or services for which people are willing to pay, competing with each other in doing so, thereby both serving public benefit and making a profit. Nonprofits typically dedicate their assets to a specific purpose that benefits society such as an educational, scientific, or charitable purpose. These two forms sometimes engage in similar or even identical activities. In the US, for example, nonprofit and for-profit hospitals compete for patients and fees in the same markets.

Nonprofits and for-profits, however, operate with different legal opportunities and constraints. For-profits raise private capital and typically pay taxes on profits. They are expected to return profits to investors; indeed, it is sometimes difficult for for-profits to embrace 
social ends, their expansive statements about stakeholder rights notwithstanding. Nonprofits embrace a broader set of purposes. Although they may make profits, they are forbidden to distribute them to private shareholders. They may also benefit from various tax advantages.

The current enthusiasm for hybrids reflects the judgment that this division of organizational world into for-profit and nonprofit entities is too stark, that it does not appropriately reflect the diverse mixtures of private benefits and public ones that organizations can provide. Seeking novel ways to structure organizations and the incentives that operate within them, social entrepreneurs have sought to combine some of the strengths and advantages of each form of organizations.

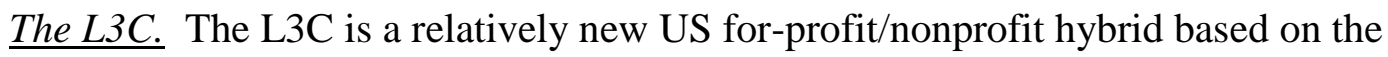
limited liability company form, which allows partners to benefit from both limited liability (in which a person's liability is capped at their investment in the company) and pass-through taxation (in which the partners are taxed individually, but the partnership is not directly taxed). Early L3C proponents sought to design an entity that would attract charitable and equity capital by removing legal barriers to for-profit enterprises receiving loans or capital investments from a particular form of charitable entity known as a "private foundation.” These advocates have persisted, unsuccessfully, in pressing federal legislation to ease the flow of private foundation funds to L3Cs. Other proponents of the form have focused more generally on the need for private capital to advance various laudable goals.

State law governs L3Cs. Vermont enacted the first L3C statute in 2008, and since then at least nine other states have passed such statutes. Several others have similar legislation pending. After passing a statute in June 2013 and incorporating over one hundred L3Cs, North Carolina 
eliminated the form in January $2014 .^{2}$ Statutes typically require that L3Cs be formed to significantly further "one or more charitable or educational purposes.” ${ }^{3}$ Although the precise number of L3Cs is unknown, as of 2012 there were over 170 registered L3Cs in Vermont ${ }^{4}$ and in 2014, over 200 in Michigan. ${ }^{5}$

Benefit and Flexible Purpose Corporations. Some US states have authorized other hybrid forms than the L3C. In 2009, Maryland was the first state authorizing benefit corporations, and by 2014 almost half the states had passed laws authorizing benefit corporations. ${ }^{6}$ Co-drafted by the Maryland legislature and B Lab - a nonprofit, charitable corporation that offers certification to businesses that amend their governing documents to reflect the goal of seeking to "solve social and environmental problems"7 -- the legislation requires benefit corporations to "have the purpose of creating a general public benefit," defined as “a material, positive impact on society and the environment, as measured by a third-party standard, through activities that promote a combination of specific public benefits.”8 The statute explicitly enables directors to consider environmental and social concerns in their corporate decisionmaking, in addition to the interests of shareholders. ${ }^{9}$ Unlike L3Cs, benefit corporations are not required to pursue charitable social purposes.

California, which also allows Benefit Corporations, was the first state to permit Flexible Purpose Corporations, entities that have the primary purpose of profit-making but also include a "special purpose” in their articles of incorporation. In addition to the charitable purposes permitted by the benefit corporation form, special purposes include charitable activities that minimize the adverse effects of a corporation's activities on its employees, suppliers, customers, and creditors, community, or environment. ${ }^{10}$ The form is meant to protect directors from 
liability if they consider social or environmental goals, instead of profits, in their decisionmaking.

Community Interest Companies. Developed in the United Kingdom through its Company Law, and currently available in England, Wales, Scotland and Northern Ireland, Community Interest Companies (CICs) were developed for entrepreneurs wishing to benefit the community, broadly defined, rather than company owners. A corporation can satisfy this requirement according to a reasonable person standard that protects against a narrow definition of the community such as "my family," "my friends," or "regular drinkers of ABC beer." requirements include an “Asset Lock,” in which both profits and any assets that exist upon dissolution cannot be distributed, except as permitted by legislation or by transfer to another CIC or a charity. The UK government, unlike US states, created a new regulatory structure to oversee the hybrid organizations. An independent public office holder known as the CIC Regulator serves as a "light touch regulator" who encourages the "development of the CIC brand and provide[s] guidance and assistance on matters relating to CICs." ${ }^{12}$ When developed, there were stringent limits on the percentage of profits that a CIC may distribute to investors. ${ }^{13}$ As of October 1, 2014, the laws were loosened to allow CICs to pay individual shareholders an unlimited amount in annual dividends subject to a cap of 35 percent of distributable profits on total dividend payments.

CICs are required to register their existence, include the CIC designation in their name, and apply to the Regulator for special community interest status. Recent tallies have identified over 6,000 registered CICs in the United Kingdom. ${ }^{14}$ 
British Columbia and Social Entrepreneurship. British Columbia has been at the forefront of Canadian efforts to embrace social entrepreneurship. ${ }^{15}$ It created Canada’s first Parliamentary Secretary for Social Entrepreneurship in 2010, an Advisory Council on Social Entrepreneurship with the mandate to increase social innovation, and an Assistant Deputy Ministers' Committee on Social Entrepreneurship organized to maximize social innovation within government. After extensive consultations about adding a new hybrid corporate form based on the British CIC model, ${ }^{16}$ in 2012 the province amended the BC Business Corporations Act to allow a new social enterprise company known as a Community Contribution Company (C3).

A for-profit company registered in BC may apply its profits to charitable endeavors or attempt to attract investors with promises that those profits will be used, in part or full, for charitable purposes. Short of private contracting between the company and its investors, however, there is no way for a for-profit to make restrictions on its purposes or shareholder payouts binding or enforceable. The province intended the new hybrid company form to address this gap.

A C3 must adopt a statement of its status in its notice of articles and include the term “community contribution company" in its name. The companies exist with several restrictions. C3s must 1) cap dividends at forty percent of annual profits plus any unused dividend amount for any previous financial year, 2) restrict transfers to qualified entities (i.e., a registered charity, a community service cooperative, or a prescribed entity or class of entities as defined in section 149.1(1) of the Income Tax Act), and 3) produce an annual community contribution report. ${ }^{17}$ Moreover, C3s are subject to an asset lock, meaning that upon dissolution the C3 may distribute 
up to sixty percent of its assets to shareholders and the rest must go to a qualified organization. Unlike the British model and a recent analogue in Nova Scotia, which has a community interest company regulator, ${ }^{18}$ there is no C3 oversight body. C3s are taxable entities and are subject to securities law.

\section{JUSTIFICATIONS FOR HYBRIDS}

Proponents of L3Cs have advanced several, more or less convincing, justifications for L3Cs that apply to hybrid organizations more generally. Some social entrepreneurs argue that hybrids will address the concern that nonprofits, unlike for-profits, are either unduly constrained by regulation or inherently inefficient. Others ground their support for hybrids in historical practice, arguing that government has always relied upon for-profits to provide public goods; the L3C merely signals a return to America's colonial corporate practices. Finally, and perhaps most convincingly, observers contend that the new legal designation will help market a company's social commitment to potential philanthropists, thereby bringing much-needed capital to social ends. Before turning to these justifications, we examine the initial goal of L3C proponents in the U.S., one that involves relieving perceived legal restrictions on certain types of nonprofit foundations on making investments in for-profit enterprises.

\section{Program Related Investments}

Understanding the primary legal justification for L3Cs in the U.S. - and its inherent contradictions - requires background regarding regulation of a nonprofit form called a private foundation. Like public charities, private foundations are legal entities meant to advance philanthropic purposes, but they typically do so through making grants rather than operating programs and their funding comes from a family or small number of people rather than from 
donations by the public. Although ordinarily exempt from income taxes, they enjoy fewer tax benefits than public charities. In the United States, Federal law also requires that they make annual distributions of at least five percent of the previous year's assets in furtherance of their charitable purpose - typically as grants to operating charities - and imposes sizeable fines if they fail to make these payouts within a two-year period. ${ }^{19}$ If they further the foundation's purposes, some or all of the five percent may be in the form of Program Related Investments (PRIs), for example below-market rate loans to for-profit businesses (once repaid, the annual payout requirement is increased by the amount of the principal repayment). ${ }^{20}$ In the canonical example, the Gates Foundation invested in a private company to accelerate the discovery, development, and adoption of health interventions designed to reduce disease in developing countries. ${ }^{21}$ The IRS has recently issued proposed regulations providing other examples of qualifying PRIs, including combating environmental deterioration and building a child-care facility in a lowincome neighborhood. ${ }^{22}$

PRIs are uncommon, less than one percent of private foundation distributions. L3C advocates believe this is because foundations find them too risky. ${ }^{23}$ The IRS may disallow a PRI if the investment does not advance a foundation's particular purpose. Having disallowed a PRI, the IRS may impose large excise taxes on the foundation and, in rare cases, personal liability on its managers. ${ }^{24}$ Although such risks are small for the many foundations with very broadly worded purposes, foundations typically draft PRI agreements carefully. Some seek advance approval from the IRS by requesting a private letter ruling, a time-consuming and expensive process -- lawyers’ fees and IRS filing fees are approximately $\$ 10,000 .{ }^{25}$ 
Some hybrid proponents and many state legislators believe that L3Cs will make the PRI process easier or even obviate the need for it altogether. ${ }^{26}$ The memorandum introducing the New York L3C legislation, for example, explained,

The business entity form and legislation were drafted with the goal of complying with federal IRS regulations relevant to PRIs by foundations. Such compliance is anticipated to make L3Cs useful vehicles for PRI investment - and . . . [, hopefully to] obviate the need for individual IRS private letter rulings $\ldots{ }^{27}$

With this goal in mind, state legislatures drafted L3C statutes to mirror the relevant regulations. Although L3C statutes may appear in amendments to corporations, LLC, or other sections of state statutes, the key provisions all use the same language as the federal regulations. They require an L3C to meet the following conditions: 1) it must significantly advance one or more charitable or educational purposes; ${ }^{28} 2$ ) it would not have formed but for the company's relationship to the accomplishment of charitable or educational purposes; and, 3) "no significant purpose of the company is the production of income or the appreciation of property; provided, however, that the fact that a person produces significant income or capital appreciation shall not, in the absence of other factors, be conclusive evidence of a significant purpose involving the production of income or the appreciation of property.”29 The L3C also may not advance political or legislative purposes as defined by the tax code.

Nonetheless, these statutes are unlikely to address the inherent challenges to raising PRI funding. ${ }^{30}$ Regardless of the applicants' legal form, private foundations considering making a PRI request must engage in an organization-specific determination for each PRI: 
That carefully takes into account the foundation's mission, the purpose of the organization receiving the investment, the relationship of the receiving organization's purpose to the foundation's mission, and how the governance and financial structure of the receiving organization ensures that the receiving organization will operate within the PRI requirements. At a minimum, the last-mentioned issue requires the foundation to carefully monitor the activities of the receiving organization. ${ }^{31}$

The IRS could loosen its standards for PRIs, but it is unlikely that the L3C form will affect "federal tax authority approval of an unduly risky, low-return, private-foundation investment ... being characterized as a ... PRI." ${ }^{32}$ It also is possible that federal L3C legislation could be drafted to provide for the rebuttable presumption of a valid PRI investment, but even that would still require individualized analysis. ${ }^{33}$ In fact, in 2013, Congress did not move on legislation -- the Philanthropic Facilitation Act -- that would streamline the PRI process. $^{34}$

To date, neither the IRS nor Congress has demonstrated any intention to streamline the process for approving PRIs or eliminate the institution-specific review process. ${ }^{35}$ In fact, the IRS has issued little advice on PRIs at all: it has issued a revenue ruling allowing a private foundation to offer low interest rate loans, otherwise unavailable, to blind people to allow them to establish their own businesses, ${ }^{36}$ and a private letter ruling permitting a foundation to make an investment in a for-profit limited liability company under terms that involved substantial ongoing control by the investing foundation to insure the appropriate use of the funds ${ }^{37}$. Moreover, Congress has increasingly policed nonprofit organizations for abuses related to funneling 
nonprofit dollars to private parties, and it is unlikely that legislators are willing to loosen nonprofit tax rules. ${ }^{38}$

Recognizing the limitations of L3Cs, a committee of the American Bar Association Business Section registered strong opposition to the new form. ${ }^{39}$ It issued a resolution stating, "the promotion of L3C legislation has led to the incorrect assumptions that ... using the L3C structure somehow facilitates the PRI process; and ... structuring an enterprise to receive PRIs can and should be simple and straightforward." ${ }^{40}$ It also emphasized the organization-specific nature of PRI letter rulings and urged "all state legislatures not to adopt L3C legislation." ${ }^{41}$ As the ABA Committee recognized, the new L3C statutes will not and cannot address the specific federal tax problem that was the ostensible reason for their creation. Because valid PRIs require a match between a funder and a recipient, one cannot awarding any organizational type or even any particular organization something akin to a PRI license or a generally-applicable PRI seal of approval.

\section{Marketing}

Hybrid companies are generally required to include their status in their name. The requirement also helps the hybrid publicize its social purpose and credibly market its intentions to potential philanthropically-minded investors. ${ }^{42}$ Indeed, early L3Cs identified the "halo-effect" as their motivation for adoption of the form. ${ }^{43}$ Other marketing methods, such as obtaining B-Corp status, may be less effective branding methods than hybrid status because they are purely voluntary and are unrecognized or regulated by the state. ${ }^{44}$ 
Nonetheless, the form itself may mislead investors and the public. Investments in PRIs, and other hybrids, "raise a host of complicated non-tax issues, including ... potential conflicts of fiduciary duty for the foundation trustees, securities law concerns, and 'exit rights' for the foundation.” ${ }^{45}$ Moreover, unlike nonprofit law, which grants oversight powers to attorneys general and tax authorities, current L3C statutes in US states do not charge any regulatory body with monitoring the missions of hybrids. Although the government imprimatur may be useful to the enterprise in raising funds, it may also mislead the public -- and even regulators -- into thinking that the government guarantees the for-profit's social mission or that the entity is exempt from rules governing for-profit investing, such as securities and solicitation rules.

Although the same challenges can be made to PRI processes, private foundations must ensure that the grantee remains qualified for the PRI and will risk excise taxes, or even loss of tax-exempt status, if they do not monitor their grantees sufficiently. Moreover, it would be difficult for even a conscientious private foundation to certify that the grantee L3C is pursuing appropriate non-pecuniary goals if the purpose of foundation investment is to subsidize private investors.

Of course one could simply treat L3Cs as charities, as the Illinois attorney general has done. This is not possible in some jurisdictions; British CICs may not obtain charitable status, although charities may establish CICs as charitable subsidiaries. ${ }^{46}$ But even where it is possible, treating hybrids as charities comes with another set of risks, such as setting precedent for regulation of other legal forms such as charitable remainder and lead trusts that have traditionally, and for good reason, remained outside the aegis of the attorney general. Unlike forprofits and nonprofits, for which people roughly understand the risks of investments or 
donations, the public and others are quite likely to misunderstand the degree to which their interests in hybrids and their activities are being monitored and protected.

\section{For-Profit v. Nonprofit Efficiency}

Social entrepreneurs commonly claim that for-profits are more efficient than nonprofits. They blame the relative inefficiency of nonprofits on, for example, 1) charities law, which forbids nonprofits from primarily seeking profits and distributing them to private owners, being unduly constraining; ${ }^{47}$ 2) the lack of competition they face; ${ }^{48}$ and, 3) rules forbidding nonprofits from making profits or rules requiring nonprofits to operate at a deficit. ${ }^{49}$ Legislators have similarly seen L3Cs as the way to apply hard-headed business methods to social problems. As New York legislators explained, "L3Cs share the operating efficiencies of a for-profit along with a reduced regulatory structure, and the social purposes of a nonprofit organization.,50

These claims are largely wrong. The over two million nonprofits in the US operate in robust markets. ${ }^{51}$ Many compete with other nonprofits (e.g., for limited charitable donations), or even with for-profit or government entities, to sell goods and services. Moreover, they are permitted to make profits and they do. Although Harvard University has lost money over the past few years, its revenues have typically been considerably greater than expenses and it reported a 2009 fund balance (net assets) of almost 31 billion dollars. ${ }^{52}$ On a smaller scale, the Girl Scouts of Southeastern Michigan earned a \$56,103 profit and held a fund balance of approximately $\$ 21$ million dollars in 2009. ${ }^{53}$

One should also not accept the view, as some do, ${ }^{54}$ that for-profits are more efficient than nonprofits, on faith. Nonprofits are permitted to use some of the management methods typical of 
for-profits. For example, nonprofits may use financial incentives -- including salary incentives and, in some cases salary incentives tied to profits -- to motivate employees to reach goals. ${ }^{55}$

Conclusions about relative efficiency depend, at least, on comparing organizations with the same goal. No doubt Goldman Sachs generates profits more efficiently than does the Grameen Bank, but it is likely less efficient at microlending. Where nonprofits and for-profits compete head-to-head to provide the same goods in the same market, evidence about relative efficiency is mixed, with many studies finding that nonprofits are superior or there is no difference in efficiency. ${ }^{56}$

\section{Historical Arguments}

Scholars have argued that government has never been able to solve social problems alone and that reliance on for-profits has an admirable historical pedigree. According to Professor Linda Smiddy, "[S]ocial enterprise is simply the newest manifestation of historically recurring efforts to use business forms and methods to achieve public goals. For example, during the postcolonial period of the United States, privately-owned enterprises built many of the country's

turnpikes and bridges - projects too large to be financed by the fledgling country’s economy., ${ }^{\text {}}$

Although social enterprise is an old concept, the historical argument has been short on critical details. Discussing public-private governance in colonial America, Professor Bill Novak explained:

A classic example of early American public-private governance was the use of waterlot grants to develop New York City's waterfront. While many have seen only private interests and perhaps more than a bit of 
private speculation and public corruption in the distribution of the city's waterfront property to private entities, Hartog portrays the waterlot system as a creative mode of public-private development and regulation. The city marshaled private energies and equity for development through the granting of private property rights while at the same time maintaining public control and regulatory oversight. ${ }^{58}$

The key point here is that the for-profit entities were under the tight control of the government. Indeed, the very use of the corporate form was understood historically not as a right held by private, profit-seeking activities but rather a privilege granted by the sovereign.

\section{Access to Capital and the Case for Hybrids}

Perhaps the most convincing justification for a new form is that it will attract new capital for social needs. Some L3C proponents have advanced a particular example of how this might happen -- leveraging PRIs to reduce risk for private investors. They have proposed an investment structure with three tranches. In the lowest level, foundations would demand the lowest returns, allowing profits to subsidize the other levels of investments. In the middle level, socially-conscious investors would accept below-market returns as the cost of investing in a market-based enterprise with social goals. At the top level, ordinary, profit-maximizing investors would demand market rates (or higher), which would be available via subsidies from the other levels of investments. ${ }^{59}$ These investors could receive a higher rate of return than they would typically earn in a similarly risky investment. More intuitively, imagine an analogous home mortgage: "the foundation would obtain a higher-risk second mortgage while the 
commercial investors obtain a first mortgage.”60 The loan structure makes the second riskier than the first, despite the investment in the same property.

On its face, the proposal seems like a winner for investors and society. What's the problem? The problem is that the structure eases restrictions on charitable assets -- tax-exempt, foundation dollars that are subsidized by the government (in the US and elsewhere) -- to increase returns for private investors, an impermissible, non-charitable purpose. Since it likely involves more than incidental profit-making, it may well violate prohibitions on private inurement in charities.

Some experts disagree. Several prominent nonprofit scholars and lawyers, including a former director of the IRS Exempt Organizations Division counter that:

Private benefit depends on all of the facts and circumstances in a given situation. In fact, a PRI ... always involves some level of private benefit, but rather than a disqualifying private benefit, it is deemed incidental to the accomplishment of charitable purposes. One example in the Treasury regulations involves a foundation making a below-market-rate loan to a "business enterprise which is financially secure and the stock of which is listed and traded on a national exchange," in order to encourage the enterprise to establish a factory in a depressed urban area. In this example, there is clearly private benefit, since the corporation receives a below-market-rate loan from charity - but the private benefit is incidental. $^{61}$ 
This rejoinder -- that although these arrangements are not inherently about serving a private benefit, some degree of private inurement exists with conventional PRIs -- is true. But that inurement exists in one situation is not a good reason to allow it in others. PRIs are a rare exception to stringent regulations because policymakers have concluded that their benefits outweigh their risks. And, unlike hybrids, the IRS closely monitors them and requires strict supervision by granting foundations. Legal forms designed to make the PRIs more commonplace will only lead to more risk of using charitable dollars to pursue profits.

Finally, there are alternatives available to profit-minded entrepreneurs and the government. ${ }^{62}$ Social entrepreneurs may form for-profit companies and donate their profits to charities. Those that do not like the limitation that corporations may only deduct up to ten percent of profits donated to charities annually ${ }^{63}$ can use the $\mathrm{S}$ corporation form used by other charitably-minded for-profits, such as Newman's Own, and avoid this stringent limit. The government may subsidize social entrepreneurs through direct grants or through the tax exemptions and deductions they already supply. It is unclear whether there is additional benefit to allowing further, unregulated tax expenditures.

Regardless of the particular forms of corporations and subsidies, the underlying argument of L3C proponents is that current legal forms are insufficient to channel adequate funding to business-minded people who want to advance the public interest. We agree that raising money is hard, and having more of it makes it more likely that founders will achieve their private and social goals. As one law review note recently observed, "The main obstacle to operating a social enterprise as a for-profit entity is the difficulty of raising capital." ${ }^{64}$ 
But this is how the market works. Using L3Cs to save failing businesses may simply be an end run around market competition. Consider, for example, that the Maine milk cooperative, MooMilk, converted to an L3C when it was unable to survive in the competitive market after it lost an important contract with Hood Milk. ${ }^{65}$ As Rush Limbaugh remarked, "So this is social engineering in the private sector. We're going to now reward businesses that do not make a profit if someone approves of their social mission." ${ }^{\text {66 }}$ Limbaugh might be correct: the failure of the cooperative is bad for some farmers in Maine, but might be good for social welfare. After all, Hood had cancelled its contract with MooMilk because it found cheaper organic milk suppliers closer to its plants in Connecticut. ${ }^{67}$

Yet some states want to use this form to prop up failing industries. The North Carolina bill was entitled "An Act to provide enhanced economic development incentives to endangered manufacturers and to clarify that a low-profit limited liability company is a limited liability company under state law," and the preamble to the bill included the statement, "Whereas, the State of North Carolina is and should be actively engaged in economic development efforts to attract and stimulate private sector job creation and capital investors; and whereas, the furniture industry in North Carolina has been damaged by overseas competition and has now become an endangered industry in North Carolina . . " "68 Even more explicitly, another advocate wrote:

An effort is underway in North Carolina to codify the L3C form and use it for furniture companies that are on the verge of going under or leaving the state. As L3Cs, these companies would be able to accept investments from private (non-profit) foundations, which would not demand as high a return on investment as would traditional for-profit investors. And as L3Cs they would qualify as PRIs, which in turn would likely open the 
deep pockets of the foundations wishing to promote the community interest of a thriving furniture industry in the state. ${ }^{69}$

US manufacturing is suffering and communities are failing because of the attendant problems. But should the government subsidize L3Cs to prop up their favorite failing industry? Alternatives, such as grants for displaced workers, industrial development bonds, or tax-exempt nonprofit community development organizations, can do the job. It is unclear why the L3C form is superior and whether using the form to protect failing industry is welfare enhancing. Although sometimes industry subsidies may be appropriate as a method to achieve the charitable goal of community development, not all industry subsidies do so. As John Tyler explains, although creating jobs and similar activities are beneficial for society, such "social ends" alone are not appropriately deemed charitable in the exempt organizations context. ${ }^{70}$

Much of this essay has focused on the inappropriateness of tax-subsidized dollars lining private pockets. But what about hybrids that do not draw on government or tax-subsidized funds? Is there anything wrong, for example, with a hybrid based entirely in the realm of taxable investments, as operates in the UK and BC?

First, keeping tax exemptions from applying to hybrids may not be so easy. Advocacy for exempting hybrid companies from taxation followed closely behind calls for allowing the form. ${ }^{71}$ The Canadian Task Force on Social Finance has encouraged pension fund investing, implementation of tax incentives for social investment, and "government incentives to kick-start the flow of private capital..72 The Parliamentary Secretary for Social Entrepreneurship Gordon Hogg, has also called for tax support for social entrepreneurship. ${ }^{73}$ And in some states, such as 
California, LLCs may be eligible for property tax exemptions if they are organized and operated for one of a list of particular purposes (e.g., a hospital) even if they are not charities. ${ }^{74}$

Regardless, suppose that no government dollars would find their way to these new entities either directly or through preferred tax status. On the one hand, one still might worry that new hybrids will crowd out private donations to fully charitable organizations, a question that is ripe for study. On the other hand, some investors might support social endeavors with low-return investments but not zero-return investments (or, rather, a return equal to the tax deduction they would get from a charitable deduction). Maybe hybrids will add new capital to socially beneficial projects, rather than crowding out nonprofits, by attracting those who believe in the relative efficiency of for-profits. ${ }^{75}$

Proponents think there are many such investors, as well as investors who won't donate to nonprofits because they cannot control their donations to their satisfaction but may donate to L3Cs if they can ensure that they remain a single dominant investor. But the restriction on managers' control of assets goes to the central purpose of a nonprofit. This restraint provides independence from the greed or motivations of individual persons (and the state). Autonomy is the genius of the nonprofit form.

This explanation exposes the deep incoherence of the hybrid form. Proponents often talk about a blending or balancing of profit-making and social purpose goals. Balancing is the better metaphor, because conflicts inevitably arise between charitable and personal goals. Although Professor Brakman-Reiser favors encouraging hybrids, she recognizes this difficulty and does not think they should be designated as nonprofit charities. ${ }^{76}$ She helpfully characterizes the CIC as a model in which: 
“[O]ther-regarding and self-regarding modes are intentionally blended.

On the one hand, the CIC must provide its benefits to some relatively large class and some core of a CIC's assets must be irrevocably dedicated to community interest or charitable purposes. On the other hand, the CIC entails a kind of equity investment where the shareholders are permitted to engage in profit-taking.,"77

John Tyler has argued that a correct understanding of the L3C form resolves the tension of fiduciaries having two masters -- the potentially conflicting duties to shareholders and to the charitable goal. Tyler addresses the tension arguing that "profit and value as ultimate purpose give way to charitable, exempt purposes,” thereby clarifying which duty comes first. ${ }^{78}$ Although statutes typically forbid L3Cs from adopting the production of income or the appreciation of property as a primary purpose, few states require L3Cs to pursue exclusively charitable purposes.

Moreover, even if Tyler's understanding is correct, it is not the typical understanding of how L3Cs will work. Nor is it clear how fiduciaries will interpret potential conflicts when push comes to shove. The example of the Grameen Bank is instructive. In his op-ed, "Sacrificing Microcredit for Megaprofits," bank founder Muhammed Yunus explained that "microcredit ... [gave] . . rise to its own breed of loan sharks,” when profit-seeking dominated social ends. ${ }^{79}$ The L3C similarly creates an irresolvable conflict between the necessary objective of the organization -- profit -- and that which is espoused as the primary goal -- mission. How this conflict will be resolved depends on how managerial decision-making takes place. Who will decide what specific activities to undertake? At what price? How will public purposes be 
balanced when all these decisions are made? The schematic L3C statutes do not address how L3Cs will answer these inevitable questions.

\section{CONCLUSION: IS THERE A ROLE FOR HYBRID ENTITIES?}

The nonprofit legal form is often criticized for being "outdated." ${ }^{80}$ Charities law is certainly old. The common law of charities derives from the Statute of Elizabeth of 1601, and lawyers in the US, UK, and Canada rely on centuries-old case law when interpreting charities law. The Canada Corporations Act has not been substantially updated since it was enacted in 1917, and the UK Charities Act of 2006 signaled the first significant change to the legal definition of charitable purposes since the $16^{\text {th }}$ century. Social entrepreneurs have embraced hybrid organizations as the next new thing that will modernize this ancient law.

But change for change's sake is seldom a good idea, and most arguments advanced in support of hybrids are unpersuasive. It is unlikely that the L3C form will increase the use of PRIs in the U.S., and even less clear that such a change would be desirable. Automating the PRI process by relying on the hybrid legal structure, particularly if the PRI is used to undergird a tranched funding model, would increase the risk that charitable assets will be used for impermissible or non-charitable purposes, allowing L3Cs to benefit either directly or indirectly in tax advantages meant only for nonprofit charities. Moreover, it might be difficult for charitable fiduciaries to attend to their nonprofit organizational duties rather than their for-profit goals.

Nonetheless, the increasing and unyielding difficulty of raising charitable capital must be addressed, and hybrids may provide one answer. Although the form has largely been limited to 
small organizations in the US, they offer an intriguing option for large nonprofits. For example, American nonprofit hospitals that are struggling to raise capital may fruitfully incorporate as a hybrid rather than convert to for-profit form.

However, we shouldn't gamble on hybrids without answering several questions. Some of them are empirical -- Will hybrids attract new entrepreneurs and new capital to social causes, thereby increasing the total capital available for social enterprise? Or will hybrids merely crowdout either charitable or public spending? Some questions are legal -- When profit-making and charitable goals conflict, which should and will prevail? To whom do directors owe their fiduciary duties? Since corporate law is largely designed to enable corporate activity, does it make sense to create a new legal form for substantive ends? Other questions are political -- for example, what is the appropriate role of government in terms of facilitating private exchange in the public interest?

To assess the promise of hybrids we need more information and analysis about the overall effects of a new form on social welfare. Unfortunately, government can be ill-suited to engage in that type of analysis. In this case, the departments that regulate business organizations such as hybrids -- typically the corporations or finance departments -- focus on enabling the creation of new entities. They do not regulate the tax or charities implications of those entities. It is not their job to do so. To assess hybrids, however, the analyst needs to consider the interactions among legal forms, tax law, and charities law.

Perhaps policy makers can learn from another of Professor Dobell’s lessons: “One of the well-known problems of collective action [is] that apparently rational individual agents acting in their own interest can be led to conduct that leaves everybody worse off . . " ${ }^{81}$ In the case of 
hybrids, there are large benefits to be had with interdepartmental cooperation. Policymakers may well decide that the benefits of encouraging social entrepreneurship, particularly the benefit of directing more money towards charitable endeavours, are worth the considerable costs of weakening the wall between the for-profit and nonprofit form (not the least of which will likely including crowding some traditional philanthropy). If they do, such a decision should be guided by comprehensive analysis that has been missing from the debate so far.

\section{${ }^{1}$ A.R. Dobell, Holarchy, Panarchy, Coyote and Raven: Creation Myths For A RESEARCH PROGRAM (Mar. 31, 2009), http://web.uvic.ca/ rdobell/assets/papers/myths.pdf.}

${ }^{2}$ Anne Field, North Carolina Officially Abolishes the L3C, ForBEs (Jan. 11, 2014), http://www.forbes.com/sites/annefield/2014/01/11/north-carolina-officially-abolishes-the-l3c/.

${ }^{3}$ VT. StAT. ANN. tit. 11, § 3001 (27)(B); (A)(i); (A)(ii) (1996).

${ }^{4}$ Vermont Secretary of State, Corporations Database, Search for "L3C," http://www.sec.state.vt.us/seek/keysrch.htm (last visited Dec. 19, 2012).

${ }^{5}$ Michigan Department of Licensing and Regulatory Affairs, Corporation Division Business Entity Search Results, http://www.dleg.state.mi.us/bcs_corp/rs_corp.asp?s_button= sword\&v_search=L3C\&hiddenField=\&search=Search (last visited February 3, 2012).

${ }^{6}$ Many states, such as New York, New Jersey, Virginia, Hawaii and California have passed similar legislation as of 2014 (Marc Lifsher, Businesses Seek State's New Benefit Corporation Status, L.A. Times, Jan. 4, 2012, http://articles.latimes.com/2012/jan/04/business/la-fi-benefitcorporations-20120104; CAL. CORP. CODE § 14600 (West 2006 \& Supp. 2014); HAW. REV. StAT. ANN. § 414D-253 (LexisNexis 2010); N.Y. Bus. CoRp. LAW § 1707 (McKinney 2003 \& 
Supp. 2014); N.J. St. ANN. § 14A:18-1 (West 2003 \& Supp. 2014); V.A. CoDE ANN. § 13.1-782 (West 2011 \& Supp. 2013)). Legislation is pending in Michigan, Idaho, Montana, Florida, New Hampshire, Kansas, Minnesota, Iowa, Alaska, Kentucky, Georgia, Alabama, Ohio, and Indiana, see Passing Legislation, CERTIFIED B CORPORATION, http://www.bcorporation.net/what-are-bcorps/legislation (last visited July 16, 2014).

${ }^{7}$ What Are B Corps?, CERTIFIED B CORPORATION, http://www.bcorporation.net/about (last visited July 16, 2014).

${ }^{8}$ Md. Code AnN., CoRps \& Ass’Ns § 5-6C-01 (LexisNexis 2007 \& Supp. 2013).

${ }^{9}$ Md Code AnN., CoRps \& Ass’Ns § 5-6C-07 (LexisNexis 2007 \& Supp. 2013).

${ }^{10}$ CAL. CoRp. CODE $\S \S 2500-2503$ (West 2014).

${ }^{11}$ Department of Business and Innovation Skills, Chapter 2: Preliminary Considerations, OFFICE OF THE REGULATOR OF COMMUNITY INTEREST COMPANIES: INFORMATION AND GUIDANCE Notes 6 (November 2012) (U.K.), https://www.gov.uk/government/uploads/system/uploads/attachment_data/file/ 211742/12-1334community-interest-companies-guidance-chapter-2-preliminary-considerations.pdf.

${ }^{12}$ Department of Business and Innovation Skills, Chapter 11: The Regulator, OFFICE OF THE REGUlATOR OF COMMUNity INTEREST COMPANIES: INFORMATION AND GUIDANCE Notes 9 (Mar. 2013) (U.K.), https://www.gov.uk/government/uploads/system/uploads/attachment_data/ file/\%20211751/13-714-community-interest-companies-guidance-chapter-11-the-regulator.pdf. 
${ }^{13}$ The dividend cap has three elements: 1) a maximum dividend per share, which started at 5\% above the Bank of England base lending rate of the paid-up value of a share and now is $20 \%$ of the paid-up value of a share; 2) a maximum aggregate dividend limited to the total dividend declared in terms of the profits available for distribution (currently 35\% of the distributable profits); and 3) a limited ability to carry forward unused dividends (now 5 years). See Sara Burgess, Chapter 6: The Asset Lock, DePARTMENT for Business, InNOvation AND SKILLS (2013) (U.K.), http://webarchive.nationalarchives.gov.uk/ 20121021151233/http://www.bis.gov.uk/assets/cicregulator/docs/guidance/12-1149-communityinterest-companies-guidance-chapter-6-the-asset-lock.pdf.

${ }^{14}$ Regulator of Community InTERest Companies, GuidAnCE: CIC Business Activities: FORMS AND STEP-BY-STEP GUIDELINES (June 16, 2014) (U.K.), https://www.gov.uk/government/publications/community-interest-companies-businessactivities/cic-business-activites-step-by-step-guidelines.

${ }^{15}$ At this writing, Nova Scotia was the only other Province to have passed hybrid legislation. There have been calls for reform in Ontario, but they have largely involved proposals to loosen restrictions on nonprofit tax law rather than broader reforms to corporate law. See e.g., Elizabeth Mulholland, Matthew Mendelsohn \& Negin Shamshiri, StRengthening the ThIRD PILlaR Of THE CANADIAN Union (2011), http://mowatcentre.ca/strengthening-the-thirdpillar-of-the-canadian-union/. 
${ }^{16}$ Interview with Jill Sinkwich, Manager, and Tona Hetherington, Policy Advisor, Financial and Corporate Sector Policy Branch, Ministry of Finance, Province of British Columbia, (July 19, 2011).

${ }^{17}$ Business Corporations Act, S.B.C. 2002, c. B-57, s. 2.2, (2014) (Can.).

${ }^{18}$ Community Interest Companies Act, S.N.S. 2012 c. C-38 (Can.) (enacted but not proclaimed in force), available at http://nslegislature.ca/legc/bills/61st_4th/3rd_read/b153.htm.

${ }^{19}$ I.R.C. §4942(a)-(e)(B) (2007).

${ }^{20}$ I.R.C. § 4942 (i)(1) (2007).

${ }^{21}$ I.R.S Priv. Ltr. Rul. 200603031 (Jan. 20, 2006).

${ }^{22}$ Examples of Program-Related Investments, 77 Fed. Reg. 23, 429 (2012).

${ }^{23}$ Malika Zouhali-Worrall, For L3C Companies, Profit Isn't the Point, CNN MonEY (Feb. 9, 2010), http://money.cnn.com/2010/02/08/smallbusiness/ 13c_low_profit_companies.

${ }^{24}$ I.R.C. $\$ 4944(c)(2006)$.

${ }^{25}$ Rev. Proc. 2011-8, 2011-1 I.R.B. 237, § 6.01(14).

${ }^{26}$ Robert Lang, The For Profit with a Nonprofit Soul: PRIs and Private Letter Rulings, AMERICANS FOR COMMUNITY DEVELOPMENT, http://www.americansforcommunitydevelopment.org/downloads/ PRIsAndPrivateLetterRulings.pdf (last visited June 19, 2014). 
${ }^{27}$ S. S3011-2011, 2011-2012 S. Reg. Sess. (memo) (N.Y. 2011).

${ }^{28}$ The statutes define "charitable” by referring to the definition found in the Internal Revenue Code sections dealing with the deductibility of individual charitable donations, i.e., gifts to "A corporation, trust, or ... or foundation ... originated and operated exclusively for religious, charitable, scientific, literary, or educational purposes, or to foster national or international amateur sports competition ... or for the prevention of cruelty to children or animals.” I.R.C. $\S 170(\mathrm{~b})(2)(\mathrm{A})(2007)$.

${ }^{29}$ VT. STAT. ANN. tit. 11,. § 3001 (27)(B); (A)(i); (A)(ii) (1996).

${ }^{30}$ Sherri Begin Welch, As L3Cs Form, Lack of Clear Criteria Leaves Room for Confusion, CRAIN’s DETROIT Business, Oct. 11, 2009, http://www.crainsdetroit.com/ article/20091011/SUB01/ 310119965/as-l3cs-form-lack-of-clear-criteria-leaves-room-forconfusion\#.

${ }^{31}$ Daniel S. Kleinberger, A Myth Deconstructed: The Emperor's New Clothes on the Low-Profit Limited Liability Company, 35 DEL. J. CORP. L. 879 (2010).

${ }^{32}$ Carter G. Bishop, The Low-Profit LLC (L3C): Program Related Investment by Proxy or Perversion?, 63 ARK. L. ReV. 243, 265-266 (2010).

${ }^{33}$ J. William Callison \& Allan W. Vestal, The L3C Illusion: Why Low-Profit Limited Liability Companies Will Not Stimulate Socially Optimal Private Foundation Investment in Entrepreneurial Ventures, 35 VT. L. REV. 273 (2010).

${ }^{34}$ Philanthropic Facilitation Act, H.R. 2832, $113^{\text {th }}$ Cong. (2013). 
${ }^{35}$ Bishop, supra note 32.

${ }^{36}$ Rev. Rul. 78-90, 1978-1 C.B. 380.

${ }^{37}$ I.R.S. Priv. Ltr. Rul. 200610020 (June 13, 2005).

${ }^{38}$ Senator Chuck Grassley, Grassley Outlines Goals for Charitable Governance, Transparency: Prepared Remarks of Sen. Chuck Grassley, United States Senate Committee on Finance (March 10, 2009), available at http://finance.senate.gov/newsroom/ranking/ release/?id=08fee686-85754bd6-9147-5c1656e52aac.

${ }^{39}$ G. Ann Baker, Did You Know? Flexibility for Entities Providing Medical Services, 30 MicH. Bus. L.J. 5 (2010).

${ }^{40}$ ABA Committee on Limited Liability Companies, Partnerships, and Unincorporated Entities, Resolution of the Committee on Limited Liability Companies, Partnerships, and Unincorporated Entities, Section of Business Law, American Bar Association: To Be Considered at the Committee's Meeting on April 23, 2010 (2010), available at http://web.archive.org/ web/20111208234828/http://meetings.abanet.org/webupload/commupload/RP519000/relatedreso urces/ ABA_LLC_Committee-L3C_Resolution_and_explanation-2-17-10.pdf.

${ }^{41} I d$.

${ }^{42}$ Elizabeth Carrott Minnigh, Low-Profit Limited Liability Companies: An Unlikely Marriage of For-Profit Entities and Private Foundations, 34 TAX Mgm’t, Est., GifTs \& TR. J. 209 (2009).

${ }^{43}$ Elizabeth Schmidt, Vermont's Social Hybrid Pioneers: Early Observations and Questions to Ponder, 35 VT. L. Rev. 163 (2010). 
${ }^{44}$ Richard Bridge, More Reflections on Legal Structures for Community Enterprise, BC CENTRE FOR SOCIAL ENTERPRISE (April 2010), http://www.centreforsocialenterprise.com/f/ More_Reflections_on_Legal_Structure_for_Community_Enterprise_April_2010.pdf.

${ }^{45}$ Kleinberger, supra note 31.

${ }^{46}$ Department of Business and Innovation Skills, Chapter 1: Introduction, OfFICE OF THE REGULATOR OF COMMUNITY INTEREST COMPANIES: INFORMATION AND GUIDANCE NOTES 9 (Nov. 2012) (U.K.), https://www.gov.uk/government/uploads/system/uploads/attachment_data/file/ 211741/12-1333community-interest-companies-guidance-chapter-1-introduction.pdf.

${ }^{47}$ Linda O. Smiddy, Introduction: Symposium: Corporate Creativity: The Vermont L3C \& Other Developments in Social Entrepreneurship, 35 VT. L. REV. 3 (2010).

${ }^{48}$ Anup Malani \& Eric A. Posner, The Case for For-Profit Charities, 93 Va. L. Rev. 2017 (2007).

${ }^{49}$ Robert Lang \& Elizabeth C. Minnigh, The L3C, History, Basic Construct, and Legal Framework, 35 VT. L. ReV. 15 (2010).

${ }^{50}$ S. S3011-2011, 2011-2012 S. Reg. Sess. (memo) (N.Y. 2011).

${ }^{51}$ James R. Hines, Jr., Jill R. Horwitz \& Austin Nichols, The Attack on Nonprofit Status: A Charitable Assessment, 108 Mich. L. Rev. 1179 (2009).

${ }^{52}$ Presidents and Fellows of Harvard College, IRS Form 990 (2009). 
${ }^{53}$ Girl Scouts of Macomb County, Otsikita Council, Return of Organization Exempt From

Income Tax, Form 990 OMB No. 1545-0047 (2009).

${ }^{54}$ Malani \& Posner, supra note 48.

${ }^{55}$ Hines et al., supra note 51.

${ }^{56} I d$.

${ }^{57}$ Smiddy, supra note 47.

${ }^{58}$ William J. Novak, Public-Private Governance, in Government By CONTRACT:

Outsourcing AND AmERICAN Democracy 29, 29-30 (Jody Freeman \& Martha Minow eds.) (2009).

${ }^{59}$ Lang \& Minnigh, supra note 49.

${ }^{60}$ Bishop, supra note 32.

${ }^{61}$ Letter from Marcus S. Owens et al. to Willard Willard L. Boyd, III (“Letter Regarding L3C”) (July 13, 2011), available at http://www.intersectorl3c.com/goopages/pages_downloadgallery/ downloadget.php?filename=16680.pdf\&orig_name=attorney_letter_-_13c_7-13-2011.pdf.

${ }^{62}$ See Hines et al., supra note 51.

${ }^{63}$ I.R.C. $\$ 170(\mathrm{~b})(2)(A)(2007)$.

${ }^{64}$ Matthew F. Doeringer, Fostering Social Enterprise: A Historical and International Analysis, 20 DuKE J. CoMP. \& INT’́ L. 291 (2010). 
${ }^{65}$ See Nancy Artz \& John Sutherland. 2010. “Low-Profit Limited Liability Companies (L3Cs): Competitiveness Implications.” Competition Forum 8 (2): 4-5 (2010); Malika Zouhali-Worrall, For L3C Companies, Profit Isn't the Point, CNN Money, Feb. 9, 2010, http://money.cnn.com/2010/02/08/smallbusiness/ l3c_low_profit_companies.

${ }^{66}$ Rush Limbaugh, Caller Asks: Should I Take a Grant?, THE RusH LimBAugh SHOw (Feb. 8, 2010), http://www.rushlimbaugh.com/home/daily/site_020810/content/ 01125112.guest.html.

${ }^{67}$ Zouhali-Worrall, supra note 65.

${ }^{68}$ North Carolina Endangered Manufacturing and Jobs Act, H.R. 769, Sess. 2009. (N.C. 2009).

${ }^{69}$ Bruce Collins, Low-Profits, Inside Counsel (Jan. 2, 2008),

http://www.insidecounsel.com/2008/01/02/lowprofits.

${ }^{70}$ John Tyler, Negating the Legal Problem of Having Two Masters: A Framework for L3C Fiduciary Duties and Accountability, 35 VT. L. Rev.117, 124 (2010).

${ }^{71}$ For a review of tax emption issues as applied to hybrids, see Lloyd Hitoshi Mayer \& Joseph R. Ganahl, Taxing Social Enterprise, 66 STAN. L. REv. 387 (2014).

${ }^{72}$ Canadian Task Force on Social Finance, Mobilizing Private Capital for Public Good 3 (2010), http://www.mcconnellfoundation.ca/assets/Media\%20Library/

Reports/FinalReport_MobilizingPrivateCapitalforPublicGood_30Nov10.pdf.

${ }^{73} I d$.

${ }^{74}$ CAL. Rev. \& TAX. Code $§ 214$ (West 2009 \& Supp. 2014). 
${ }^{75}$ Although the article does not address this issue explicitly, a new working paper argues that some entrepreneurs who want to pursue both profits and public purposes will be able to use the new forms to do so through building public purposes into the organizing documents and, thereby protecting them, see Joseph W. Yockey, Does Social Enterprise Law Matter?, 66 ALA. L. REV. (forthcoming 2014). The article does not, however, address how the form will resolve conflicts between public benefit goals and profit-making goals when these arise, since corporate documents can simply be amended.

${ }^{76}$ Dana Brakman Reiser, Governing and Financing Blended Enterprise, 85 CHI.-KENT L. REV. 619, 647 (2010).

${ }^{77}$ Dana Brackman Reiser, Charity Law’s Essentials, 86 Notre Dame L. Rev. 1 (2011).

${ }^{78}$ Tyler, supra note 70, at 139.

${ }^{79}$ Muhammad Yunus, Sacrificing Microcredit for Megaprofits, N.Y. TimEs, Jan. 14, 2011, at A23.

${ }^{80}$ Fraser Valley Centre for Social Enterprise, Analysis of CIC and L3C Social Enterprise Forms (2008), http://www.centreforsocialenterprise.com/f/L3C_and_CIC_social_enterprise_models_Oct_2008. doc.

${ }^{81}$ DobeLL, supra note 1. 